Canadian Journal of Higher Education

Revue canadienne d'enseignement supérieur

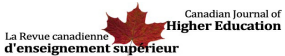

\title{
Book review of "A Perfect Mess: The Unlikely Ascendancy of American Higher Education"
}

\section{Keltie Jones}

Volume 48, Number 2, 2018

URI: https://id.erudit.org/iderudit/1057110ar

DOI: https://doi.org/10.7202/1057110ar

See table of contents

Publisher(s)

Canadian Society for the Study of Higher Education

ISSN

2293-6602 (digital)

Explore this journal

Cite this review

Jones, K. (2018). Review of [Book review of "A Perfect Mess: The Unlikely Ascendancy of American Higher Education"]. Canadian Journal of Higher Education / Revue canadienne d'enseignement supérieur, 48(2), 186-188.

https://doi.org/10.7202/1057110ar 


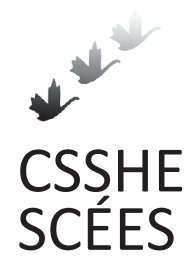

Canadian Journal of Higher Education Revue canadienne d'enseignement supérieur

Volume 48, No. 2, 2018, pages 186 - 188

\title{
Book Review / Compte rendu
}

\author{
Labaree, David F. (2017). A Perfect Mess: The Unlikely Ascendancy of \\ American Higher Education. Chicago: The University of Chicago Press. Pag- \\ es: 222. Price: 25.0o USD (hardcover).
}

Reviewed by Keltie Jones, Assistant Dean, Faculty of Agriculture, Dalhousie University.

In A Perfect Mess: The Unlikely Ascendancy of American Higher Education, David Labaree presents a history of the modern American (and, to some extent, North American) higher education system, describing how it has evolved and explaining why it works. While he approaches the analysis as an historian, which is his academic field, rather than through organizational theory, he does delve into the organizational elements that contribute to the success of the system. As someone who studies organizational behaviour in academia and has attended and worked at public and private universities and colleges in both the United States and Canada, I was interested in how this author would approach explaining how these complex systems work. In the end, I realized that the book was an extended argument for resisting external attempts to reform higher education by demonstrating that the system, although flawed, works.

The first four chapters of the book provide a detailed history of how the higher education system in the United States has evolved. Subsequent chapters focus on the role the system plays in providing access to education, the role government funding has played in expanding the system, and how different tiers have evolved and connect to each other. The first universities in the United States were modeled on the British Oxbridge system. They were places where the elite sent their sons to mature and develop the social and business connections they would need to thrive in business and society. Many institutions were established by religious orders to train ministers and expand their influence in their local areas. Eventually, most American universities adopted the German research model, where universities extended their focus from undergraduate education to include research and graduate student training. Growth was driven by demand and changes in the primary and secondary educational systems. As more people had access to secondary schools, the demand for access to college and university grew. While initially all universities were private, the state governments began to open colleges and universities to meet the growing demand, including land-grant universities mandated to provide practical and applied education and research. 
Common themes in the evolution of the system are upward mobility and balance. The increased demand for higher education has been driven by desire to gain social advantages. In meeting this demand, the American post-secondary system has faced the challenge of balancing the need for increased access with the desire for exclusivity. In Chapters 6 and 7, Labaree presents an interesting theory that the American higher education system is built on the idea that university education and research should be a private good rather than a public good. In other words, it is something that individuals, rather than the public generally, benefit from and should pay for. Thus, government investment in all levels, but most significantly in public universities, has declined. In Chapters 5 and 8, Labaree describes how the varying levels of access in the tiered system (from open access at community colleges to extreme selectivity at the highest ranked private universities) allow for broader opportunities, but maintain the superiority of the upper echelons. While it appears that the post-secondary system supports the American egalitarian ideals, it is really providing a false sense of equal access. At the same time, the universities in particular have become very good at combining an undergraduate focus with research, thereby helping to maintain the populist connection, which balances the American tendency toward anti-intellectualism.

So how does this analysis relate to the Canadian system? There are many similarities in our systems, including how universities evolved from religious institutions to the modern research model. Like the US, we have tiers within our system, from the "research intensive" U-15, to undergraduate-focused universities, to community colleges (many of which are making the move to grant degrees). However, our universities are a blend of the public and private models in the US. We have independent governing boards, but receive a significant amount of government funding, which comes with limited control over tuition decisions. The pathways between community colleges and universities in some provinces are not as developed as in the US, but there are excellent examples of these articulations in both BC and Alberta. Competition among institutions is not strictly market-driven, with provincial/regional higher education commissions limiting the ability to offer competing programs without proof of market need. We are, in general, still treating post-secondary education as a public good rather than a private good. In spite of these differences, we have sufficient areas of commonality with the American higher education system to make many of the observations in this book relevant for Canadians.

As noted above, $A$ Perfect Mess is essentially an extended argument against external reform initiatives. It is an appreciation of the American higher education system, not a critique. By explaining how it has evolved so far, Labaree is making the argument that the system should be allowed to continue to evolve rather than be "reformed," because there could be unintended consequences. He ends the book with this admonition: "So let me leave you with one thought: Why ruin a perfect mess? In order to enjoy its benefits, we need to leave it alone." (Labaree, p. 196). However, I wonder if this warning against reform is too simplistic. Throughout the book, he notes instances of how the system has evolved to adjust to external factors, so protecting the system from external shocks may result in stagnation. Rather than simply dismissing external reform efforts, perhaps we should be looking at the impetus behind them and adapting to the environmental changes they represent.

This book is an interesting read. It is informative (even if a bit repetitive) and provides valuable insights for any Canadian who is considering positions south of the border. They 
should be cautioned, however, that some of Labaree's broad statements were not supported by citation and may be more urban legend than fact, products of the elitism in the system he describes. For example, he asserts more than once (without citation) that community college transfers have difficulty competing at university and are not as well-prepared as other students. This is not consistent with my own experience working in both the California Community College and University of California systems, where transfer students were frequently identified as being the best students in the upper division courses. I was also surprised that he did not address the impact of external accrediting bodies, which are becoming more proactive in directing how universities and colleges develop and evaluate programs (and whose endorsement is required in order for an institution to receive federal funds). Perhaps the reference to external reforms was prompted by some of these activities. In the end, this book does provide a deeper understanding of how our systems and organizations have evolved, which could help faculty and administrators facing reform efforts to formulate explanations for the impact proposed changes could have. 